\title{
Position of Whistleblower and Justice Collaborator In Corruption Crime
}

\author{
Suisno $^{1}$, Enik Isnaini ${ }^{2}$ \\ Suisno72@gmail.com, enikisnaini@gmail.com \\ ${ }^{1,2}$ Faculty of Law Universitas Islam Lamongan
}

\begin{abstract}
This research is aims to know the arrangement of whistleblowers Jo Juctise collaborator in no criminal corruption other than that this article also aims to find out enforcement of whistleblower jo juctise collaborator in no criminal corruption, Using a normative juridical method of study can be concluded, that in the arrangement of whistleblower jo juctise collaborator in no criminal corruption is obvious to any witnesses and victims of legal arrangements against whistleblower jo juctise collaborator Collaborato in criminal acts can be concluded that is tetera in the law only the protection of witnesses and victims is set in law number 13 year 2006 and Whtleblower and Justice Collaborato set in the SEMA No 4 year 2011corruption. The enforcement of whistleblower and justice Collabolator still uses weights in the Law No. 20 of 2001 on the Eradication of corruption and is also in the case of SEMA to strengthen the protection of witnesses and victims.
\end{abstract}

\section{Keywords: Whistleblower, Justice Collaborator, Corruption Crime}

\section{Introduction}

A situation at this time is very heartbreaking, such as being hit by a disaster when listening to a corrupt must be free from all lawsuits and allowed to roam around enjoying state money which is the money of the Indonesian people. These are workers for the people of Indonesia and law enforcement officials to eradicate corruption because those who can find out whoever has committed a criminal act of corruption are from the authorities, and in order to achieve a country that is free from criminal acts of corruption. 
In Indonesia, the practice of corruption has become common knowledge by people who do not know anything, small or large, by government officials from the top and middle and lower levels who are in Indonesia, therefore I want to know how the evidence is especially the case of the contents of the witnesses. So the perpetrator or the victim is to find out about the corrective action taken by the first victim through the closest person, if it is said that the person closest to the agency is an employee, and the employee must really report what really happened

The development of corruption in the past to the present era has continued to be of particular concern to the Indonesian people. Corruption has started since the beginning of human life in society until now it is still unclean with the existence of criminal acts of corruption.

The public must also know the mechanism of proof of corruption so that the prevention of corruption is always maintained in front of the community and also do not know the handling mechanism nor know proof so that when the community experiences a criminal act, they already know how the proceedings are Proof of this act of speech is also through the whistle blower, namely disclosing the facts of violations. In a criminal act of corruption or also known as the opening of disgrace in a related agency.

According to Law Number 31 Year 1999 in conjunction with Law Number 20 Year 2001 concerning corruption eradication, which is included in the criminal act of corruption is anyone who is categorized as against the law, treats the act of enriching himself or herself. take advantage of positions and positions that can harm state finances or the country's economy.

And also proof of a criminal act of corruption also through justice collaborator as a perpetrator of a certain criminal act, but not the main perpetrator, who confesses his actions in an agency.

According to Sarlio W. Sarwano, there is no exact answer regarding the cause of corruption, but two things are clear, namely: ${ }^{1}$

1. Inner drive (desire, desire, will) 2016 h. 2

${ }^{1}$ Chatrina Darul Rosikah, Dessy Marliani Listianingsih, pendidikan anti korupsi sinar grafika jakarta 
2. External stimuli (friends, opportunity, lack of control)

Andi in his certification made an inventory of several causes of corruption, namely: ${ }^{2}$

1. Less salaries for civil servants than the need is likely to increase.

2. Indonesian cultural or cultural background which is the source or cause of the smooth running of corruption.

3. Poor management and ineffective and efficient controls that give people opportunities for corruption.

4. Modernization of the development of corruption

With the existence of a circular letter from the Supreme Court regarding witness protection, it is very helpful for reporters and witnesses so that it creates a courageous attitude in revealing a criminal act against the perpetrator of a crime so that the evidence mechanism by investigators in the arena of corruption can be known to the Indonesian public.

In line with the journey of eradicating corruption in Indonesia, there have been many legal breakthroughs or strategies used in law enforcement. New breakthroughs used in the eradication of corruption, such as providing legal protection for everyone, usually victims, who later testify to provide information to investigators about the ins and outs of criminal acts that they know and hear about themselves, this breakthrough is commonly known as a whistle blower. Another case with Justice Collaborator, which is the provision of legal protection which is not only limited to physical but also negotiable "reliefs", and this is usually given to one of the suspects / defendants whose role is the lightest who can be used as a witness in the same case and can be used as a witness in the same case. I am acquitted of criminal prosecution, if he can help uncover the criminal act of corruption. I will discuss these two legal breakthroughs in my writing this time, as follows:

However, the Indonesian Criminal Procedure Code (KUHAP) does not yet regulate the provisions regarding both whistle blowers and justice collaborators except the Republic of Indonesia Law Number 13 of 2006 concerning Witness / Victim Protection. This law also does not give "special rights" to a justice collaborator, except for a "whistle blower". Legal protection for justice collaborators is not limited to physical matters but also "reliefs" that can be offered. This relief is good in determining the size of the prosecutor's demands or the

\footnotetext{
${ }^{2}$ Maidin Gultom,. Suatu Analisis Tentang Tindak Pidana Korupsi PT refika aditama Medan 2018, h.5-6
} 
sentence to be imposed by the judge at trial or even the possibility of being exempted from prosecution. Justice collaborators have provided relief for the 2003 UN Convention Against Corruption and the 2000 UN Convention Against Organized Crime which has been ratified by Indonesia.

The formulation of the problem is made with the aim of solving the main problems that arise in a clear and systematic manner. The formulation of the problem is used to emphasize the problems to be studied, so that it will make it easier for the research to be carried out and will be according to the objectives applied. Based on the description above, the problems to be examined in this study are as follows: How is the arrangement for whistleblower jo juctise collaborator in not criminal corruption?

\section{Sub Title}

The regulations governing whistleblowers and justice collaborators in the territory of Indonesia are several regulations or circular letters in the industrial area, namely:

1. SEMA (circular letter of the Supreme Court) No. 4 of 2011 SEMA regulates the treatment for whistleblowers and saski who cooperate with (justice collaborators) or are involved in certain criminal cases.

2. SEMA (circular letter of the Supreme Court) No. 11 of 2011 the regulation regulates court decisions on corruption.

3. RI Law No. 20 of 2001 the regulation is amendments to the rule or uu no 31 of 1999 which regulates fighting corruption.

And there are several others, which will be discussed below Some witnesses who have received separation or detention and can also meet the qualifications for transfer from their environment or have received the conviction of the community.

Before we talk about the regulations that are in the Indonesian territory, in the country Italy has a basic legal system of regulating the protection of witnesses or what is called (or collaborator with juctice) which is regulated in the regulation or Law No. 8, 15 January 1991.

And then it has been resolved in Law No. 82, March 15 - 1991 later it was amended by law no. 45 of 13 February 2001, this provision has only been triggered by kidnapping and 
protection of scans in cooperation with justice or with law enforcement but this time only whistleblowers and justice collaborators are used.

By being brought to the Indonesian territory called the united nations convention, having several parents named UNCAC and UNTOC, then in the form which is called UUPSK which regulates Whistleblower and Justice collaborator but there is also a law which explains the protection of witnesses and victims, namely being in Article 1 of Law No. 31 of 2014.

1. A witness is a person who can provide an account for the benefit of the investigator, prosecutor and examination in court proceedings that discuss criminal acts that he has heard or seen for himself but is not a source from another person.

2. The perpetrator's witness is a person who is indicated or is a suspect or defendant and can also be said to be a convict who collaborates with the civilian apparatus or with law enforcement to uncover the problems of criminal acts of corruption.

3. A reporter is a person who only provides a report on the incident of a criminal act or provides information or information to law enforcers who directly handle criminal acts that will, are currently and have occurred.

4. Witness and victim protection agency which is abbreviated as LPSK is an institution that has the duty or authority to the community to provide protection or other rights to witnesses which should be regulated in this law.

5. The victim is a person who has been recruited by another person, who has been harmed mentally, physically, economically, because of the behavior or incidents of criminal acts or acts against the law.

6. Threats are behaviors that create or result in direct or indirect consequences that cause witnesses or victims to feel afraid or are forced to do something that is willing to give testimony in the court process.

For implementing regulations in the provisions regarding the role of the community in efforts to prevent and eradicate corruption crimes that are contained in Law no. 31 of 1999 
is PP. 71 of 2000 which regulates the mechanism for the role of the community and the provision of rewards in preventing and eradicating corruption, in article 5.

Paragraph (1) states that "Every person or every community organization or other institutional institution that can provide information accompanied by detailed details regarding allegations for perpetrators of criminal acts of corruption, law enforcers themselves provide or have the right to provide legal protection in the form of legal status and security in their lives "and this protection will not be given if the results of this investigation find very strong evidence to the reporter, those who participate in or are involved in the reported crime and this protection will not be given to the reporter who is charged with a lawsuit in another case protection regulated in this joint regulation. ${ }^{3}$

To equalize the vision and mission regarding whistleblowers and justice collaborators so that a joint regulation has been signed by the minister of law and human rights, the attorney general, the police chief, and the head of the witness and victim protection agency (LPSK) the joint regulation regulates witness protection whistleblowers and perpetrator witnesses who have very good cooperation, and also have content as a consideration for a memorandum of understanding which contains: ${ }^{4}$ Managing requests for protection of witnesses and victims in cases of corruption or other serious violations and causing witnesses and victims who endanger their lives. ${ }^{5}$

According to Lilik Mulyadi, there are two roles for whistleblowers, namely as a reporter and as a witness. Mulyadi further explained the two roles in detail as described below: 6

First, whistleblowers who only act as reporters. This dimension means that the person concerned does not directly hear, see or know the implementation of a criminal act. Strictly speaking, whistleblowers are only limited to knowing information which is then useful for disclosing facts of criminal acts by law enforcers.

\footnotetext{
${ }^{3}$ Sigit Artantotojati, Perlindungan Terhadap Saksi Pelaku Yang Bekerjasama, Bina Aksara, Jakarta, 2012, page 56

${ }^{4}$ Likmulyadi, perlindungan hukum whistleblower dan justice colaborator , alumni, bukit pakar timur, 2015, page.,86

${ }^{5}$ Mahrus Ali, Dasar-Dasar Hukum Pidana, Sinar Grafika, Jakarta, 2011, page. 97.

6 Sigit Artantojati, 2012, Perlindungan Terhadap Saksi Pelaku Yang Bekerjasama (Justice Callaborators) Oleh Lembaga Perlindungan Saksi Dan Korban (LPSK), Tesis, Program Studi Magister (S2) Ilmu Hukum Universitas Indonesia, page. 56.
} 
Second, whistleblowers who act as reporting witnesses. This dimension means that the person concerned is a whistleblower who reports and directly knows, sees and experiences himself having been, is or is about to have a criminal act that actively reports it to the authorized law enforcement apparatus.

However, both are still protected in law enforcement areas in accordance with Article 10 paragraph (1) of Law no. 13 of 2006, witnesses, ${ }^{7}$

\section{Conclusion}

The whistleblower function is a facility where an employee or stakeholder who sees some form of error can independently and anonymously report actions for the company or regulatory body with no fear of retaliation. The Whistleblower program has existed for several years to support US federal contracting law, health and safety regulations, and others. SOx, however, has moved these rules into the business offices of all US public companies. The audit committee establishes these whistleblower procedures, but other functions, such as the ethics department, HR, or internal audit, do govern them.

\section{Bibliography}

Chatrina Darul Rosikah, Dessy Marliani Listianingsih, pendidikan anti korupsi sinar grafika jakarta 2016

Maidin Gultom, 2018, Suatu Analisis Tentang Tindak Pidana Korupsi PT refika aditama Medan

Lilik Mulyadi, 2015, Perlindungan Hukum Whistleblower dan Justice Collaborator Dalam Upaya Penanggulangan Organized Crime,Alumni, Bandung.

Peter Mahmud Marzuki, 2005, Penelitian Hukum, Kencana Prenada Media Group,Jakarta.

Sigit Artantotojati, 2012, Perlindungan Terhadap Saksi Pelaku Yang Bekerjasama, Bina Aksara, Jakarta.

Ridwan Zachrie Wijayanto, 2009, Korupsi Mengorupsi Indonesia, Gramedia Pustaka Utama, Jakarta.

${ }^{7}$ Ridwan Zachrie Wijayanto, Korupsi Mengorupsi Indonesia, Gramedia Pustaka Utama, Jakarta, 2009, page 18 . 
Fakultas Hukum - Universitas Islam Lamongan

Jl. Veteran No. 53 A Lamongan

Email : fh@unisla.ac.id

ISSN Online : $2775-1090$ ISSN Print : $2775-2011$

https://jurnalhukum.unisla_acid/index.php/independent

$\neg$ 